\title{
A SARS-CoV-2 vírus magyarországi megjelenésének kimutatása légúti minták retrospektív vizsgálata alapján
}

\author{
Szalai Bálint ${ }^{1}$ - Hercegh Éva ${ }^{1}$ - Magyar Nóra ${ }^{1}$ - Déri Dániel ${ }^{1}$ \\ Rózsa Mónika ${ }^{1}$ - Molnár Zsuzsanna dr. ${ }^{2}$ - Kuti Dávid ${ }^{1}$. Kis Zoltán dr. ${ }^{1,3}$ \\ Szomor Katalin dr. ${ }^{1}$. Takács Mária dr. ${ }^{1,3}$ - Barcsay Erzsébet dr. ${ }^{1}$ \\ ${ }^{1}$ Nemzeti Népegészségügyi Központ, Mikrobiológiai Referencia Laboratóriumi Főosztály, \\ Virológiai Laboratóriumi Osztály, Budapest \\ ${ }^{2}$ Nemzeti Népegészségügyi Központ, Járványügyi és Infekciókontroll Főosztály, \\ Járványügyi és Védőoltási Surveillance Osztály, Budapest \\ ${ }^{3}$ Semmelweis Egyetem, Általános Orvostudományi Kar, Orvosi Mikrobiológiai Intézet, Budapest
}

\begin{abstract}
Bevezetés: Magyarországon 2020. március 4-én sikerült először kimutatni a SARS-CoV-2 jelenlétét két iráni beteg felső légúti mintájában. Az első pozitív esetek megjelenését követően felmerült a kérdés, hogy a vírus mikor kerülhetett be Magyarországra, esetleg okozott-e korábban megbetegedést. 2020. március 4-ét megelőzően a kifejezetten SARS-CoV-2-vizsgálatra beküldött 224 légúti minta közül egyetlen sem bizonyult pozitívnak a fent említett 2 minta kivételével.

Célkitüzés: A Nemzeti Népegészségügyi Központ Légúti Vírusok Nemzeti Referencia Laboratóriuma célul túzte ki, hogy a 2020. január 1. és 2020. április 19. között légútivírus-vizsgálatra beérkezett mintákat visszamenólegesen megvizsgálja az új koronavírus irányában.

Módszer: A tanulmányhoz felhasználtuk egyrészt az influenzafigyelő szolgálatban részt vevő, virológiai mintavételezésre is felkért (ún. sentinel) orvosok által rendszeresen vett, hetente beküldött légúti mintákat, másrészt az egyéb, diagnosztikus céllal beérkezett beteganyagokat. A vizsgálatokat real-time PCR-módszerrel végeztük.

Eredmények: A sentinel orvosok által beküldött 465 légúti mintából egy sem bizonyult SARS-CoV-2-pozitívnak. Az egyéb (nem SARS-CoV-2) légúti diagnosztikus vizsgálatra érkező 551 minta között sem találtunk március 4-e elött vett pozitív mintát.

Következtetések: Ezen adatok alapján valószínúsíthető, hogy az elsőként 2020. március 4-én diagnosztizált esetek előtt a SARS-CoV-2 nem okozott klinikai tünetekkel járó fertőzést az országban.
\end{abstract}

Orv Hetil. 2020; 161(38): 1619-1622.

Kulcsszavak: SARS-CoV-2, COVID-19, légúti vírus surveillance, retrospektív vizsgálat

\section{Detection of the first appearance of SARS-CoV-2 virus in Hungary based on retrospective testing of respiratory samples}

Introduction: In Hungary, SARS-CoV-2 was first detected in the swab samples of two Iranian patients on March 4, 2020. After finding the first positive cases, the question arose whether the virus had entered Hungary and caused infections before this date. Before March 4, 2020, except for the two above-mentioned samples, none of the 224 swab samples received specifically for SARS-CoV-2 tested positive.

Aim: The National Reference Laboratory for Respiratory Viruses of the National Public Health Center aimed to carry out a retrospective study of the swab and other samples taken for testing respiratory virus infections between January 1, and April 19, 2020 sent by sentinel physicians within the influenza surveillance for diagnostic purposes. Method: For the study, we used swab samples taken weekly by sentinel physicians of the influenza surveillance service, and other samples received for diagnostic purposes. Tests were performed using real-time PCR.

Results: All the 465 swab samples sent by sentinel physicians were found to be SARS-CoV-2 negative. Also, of the 551 samples collected for diagnostic reasons of other respiratory viruses, no SARS-CoV-2 positive was found among those taken before March 4.

Conclusion: Based on our data, it is very likely that prior to the first cases diagnosed on March 4, 2020, SARS-CoV-2 did not cause clinically symptomatic infections in Hungary. 
Keywords: SARS-CoV-2, COVID-19, respiratory virus surveillance, retrospective study

Szalai B, Hercegh É, Magyar N, Déri D, Rózsa M, Molnár Zs, Kuti D, Kis Z, Szomor K, Takács M, Barcsay E. [Detection of the first appearance of SARS-CoV-2 virus in Hungary based on retrospective testing of respiratory samples]. Orv Hetil. 2020; 161(38): 1619-1622.

(Beérkezett: 2020. július 22.; elfogadva: 2020. július 30.)

\section{Rövidítések}

$\mathrm{BAL}=$ bronchoalveolaris lavage COVID $-19=$ (coronavirus disease 2019) koronavírus-betegség 2019; IgG = immunglobulin-G; IgM = immunglobulin-M; MERS = (Middle East respiratory syndrome) közel-keleti légzési szindróma; NNK = Nemzeti Népegészségügyi Központ; PCR $=$ (polymerase chain reaction) polimeráz-láncreakció; RNS = ribonukleinsav; RSV = respiratory syncytial vírus; SARS $=$ (severe acute respiratory syndrome) heveny akut légzési szindróma; SARS-CoV-2 = (SARS coronavirus 2) SARS-koronavírus-2; VTM = Vírus Transzport Medium; WHO = (World Health Organization $)$ Egészségügyi Világszervezet

Kína 2019 végén jelentette be egy új kórokozó megjelenését az országban, amely súlyos légúti szindrómát okozott Vuhan városban (Hupej tartomány). A koronavírusok csoportjába tartozó kórokozó elnevezése - többszöri változtatás után - SARS-CoV-2 (severe acute respiratory syndrome coronavirus 2) lett. A vírus által okozott megbetegedés az angol elnevezés után a COVID-19 (coronavirus disease 2019) nevet kapta. Az új koronavírus-járvány Közép-Kína legnépesebb városából, Hupej tartomány székhelyéről, Vuhanból indult ki, máig tisztázatlan körülmények között, valószínúsíthetően zoonotikus forrásból [1]. A SARS-CoV-2 a többi koronavírusra jellemzően elsősorban légúti terjedésû vírus. A rendelkezésre álló adatok alapján, illetve részben becslések szerint a fertőzések mintegy $80 \%$-ában nem okoz tüneteket. A tünetmentes hordozók fertőzőképességéről egyelőre nem áll rendelkezésre elegendő adat. A fertőzöttek 20\%ában megjelenő vezető tünetek a láz, a légszomj és a száraz köhögés. Az influenzaszerű (esetleg gastrointestinalis) tünetek mellett megjelenő íz- és szagérzékelés néhány napig tartó elvesztése az egyik legjellemzőbb klinikai diagnosztikai szempontból. A súlyosabb esetekben kialakuló kétoldali tüdőgyulladás miatt a betegek egy része oxigénpótlásra is szorul, illetve sok esetben indokolt az intenzív terápia, a lélegeztetőgép használata [2]. A WHO adatai szerint a világon az azonosított fertőzöttek mintegy 4\%-a hunyt el ez idáig [3].

Az embereket fertőző koronavírusok a Coronaviridae család Orthocoronaviridae alcsaládjának Alphacoronavirus (NL63, 229E törzsek) és Betacoronavirus (OC43, HKU1, SARS, SARS-CoV-2, MERS-törzsek) nemzetségébe tartoznak. Magyarországon az említett törzsek közül négy (OC43, 229E, NL63, HKU1) már régóta jelen van [4]. Ezek a vírustörzsek többnyire náthát, felső légúti tüneteket, ritkán alsó légúti tüneteket vagy enteritist okoznak, de a fertőzés általában nem igényel különösebb kezelést.

A 2003-ban járványt okozó SARS- (severe acut respiratory syndrome) vírust a megjelenés évében nem sikerült Magyarországon azonosítani, bár később SARSvírus elleni ellenanyagot találtak egy betegben [5]. A 2012-ben megjelent MERS- (Middle East respiratory syndrome) vírus szintén nem jelent meg Magyarországon, importált esetet sem jelentettek. A SARS- és a MERS-vírus súlyos klinikai tünetekkel járó, sokszor halálos kimenetelü megbetegedést okoz, azonban csak nagyon közeli kontaktussal terjednek.

A SARS-CoV-2 terjedése gyorsabb, mint a SARS- és a MERS-vírus terjedése, és képes súlyos kórlefolyást okozni, ám a súlyos tünetek megjelenése ritkább. Az előző két kórokozóhoz hasonlóan eredetileg a SARS-CoV-2 is zoonotikus, azaz állati eredetú vírus, de a humán gazdaszervezethez adaptálódva ma már emberról emberre terjed, vagyis humán kórokozóvá vált.

A Nemzeti Népegészségügyi Központ Légúti Vírusok Nemzeti Referencia Laboratóriuma (a továbbiakban: Laboratórium) folyamatosan végzi a különböző légúti vírusok molekuláris és szerológiai vizsgálatát, izolálását diagnosztikai és járványügyi célból. A Laboratórium az influenza surveillance keretében vizsgálatokat végez az influenzaszerü megbetegedések monitorozása érdekében a valós kóroki háttér felderítésére minden év 40. hetétől a következő év 20. hetéig. Az influenzafigyelő szolgálatban részt vevő háziorvosok és házi gyermekorvosok által ellátott praxisokhoz tartozó páciensek a lakosság $20 \%$-át fedik le. A 20\%-os minta tükrözi a lakosság korösszetételét, illetve földrajzilag az egész országot lefedi. Az évente mintegy 1350, az influenzafigyelő szolgálatban részt vevő orvos közül 100 orvos küld az influenzaszerü tünetekkel újonnan jelentkező betegektől rendszeresen, hetente legalább egy alkalommal légúti mintát virológiai vizsgálatra. A virológiai mintavételezésre is felkért orvosokat sentinel (örszem) orvosoknak nevezik.

A sentinel orvosok által beküldött felső légúti mintákon kívül a Laboratórium hagyományos beküldésból származó alsó és felső légúti mintákat (orr/garat minták, bronchoalveolaris lavage (BAL), tracheaváladék, boncanyag) is vizsgál, amelyeket kórházak, klinikák küldenek be. Ezeket a mintákat, illetőleg az ezekből nyert virális 
RNS-t további vizsgálatok céljából megfelelően tároljuk, ezért lehetőség van a később felmerült vírusfertőzések igazolására is.

\section{Célkitüzés}

Az első SARS-CoV-2-fertőzéseket 2020. március 4-én igazolta két iráni diáknál a Laboratórium. Felmerült a kérdés, hogy valójában mikor kerülhetett be a vírus Magyarországra. Az influenza surveillance keretében a sentinel orvosok által beküldött mintákat, illetve a hagyományos járó- és fekvőbeteg-ellátó intézetekből diagnosztikus céllal beérkezett mintákat felhasználva lehetőségünk volt retrospektív módon megvizsgálni, hogy 2020 márciusa előtt jelen volt-e a SARS-CoV-2 Magyarországon. Ezért célul tüztük ki, hogy a rendelkezésre álló minták vizsgálatával pontosítjuk vagy igazoljuk a SARS-CoV-2 megjelenésének valós dátumát Magyarországon.

\section{Módszer}

\section{Betegminták}

A Laboratóriumba 2020. március 4. előtt 224 olyan minta érkezett, amelynél a beküldő orvos SARS-CoV2-vizsgálatot (is) kért.

A retrospektív vizsgálatokhoz 465 , sentinel orvosoktól származó orr/garat mintát és 551, hagyományos beküldésből (fekvőbeteg-ellátó intézetből) származó mintát használtunk fel. Az 551 minta közül 416 orr/garat minta, 55 bronchoalveolaris lavage, 79 tracheaváladék és 1 boncanyag volt. Ezeknél a mintáknál a beküldő orvos nem kért SARS-CoV-2-vizsgálatot. Minden orr/garat minta a Laboratórium által kiadott Vírus Transzport Médiumban (VTM), meghatározott szállítási körülmények között érkezett vizsgálatra. A beküldés minden esetben követte az NNK Mintavételi irányelveit [6].

\section{Vizsgálati módszer}

A mintákból a virális nukleinsavat MagNA Pure LC nukleinsav-tisztító robot segítségével MagNA Pure LC Total Nucleic Acid Isolation (F. Hoffmann-La Roche AG, Bázel, Svájc), tisztítókittel a gyártó utasításai szerint vontuk ki. A SARS-CoV-2-vizsgálatokat a Roche Diagnostics LightCycler® 480 Instrument II készülékével, a Detection Kit for 2019 Novel Coronavirus (2019-nCoV) RNA (PCR-Fluorescence Probing, Da An Gene Co., Ltd. of Sun Yat-sen University, Guangzhou, Guangdong, Kína) módszerrel végeztük a gyártó előírásai szerint.

Akkor tekintettünk pozitívnak egy mintát, ha mind a minta-RNS-t, mind a belső kontrollt mérő csatornán kevesebb, mint 35 ciklusszámon belül amplifikáció volt detektálható. Ha a belső kontroll pozitív jelet adott, de a minta nem adott jelet, akkor az eredményt negatívnak értékeltük. A real-time (valós idejü) PCR-futtatások során externális pozitív és negatív kontrollt is használtunk.

\section{Eredmények}

A március 4-ig SARS-CoV-2-vizsgálatra beérkezett 224 minta közül csak 2 iráni páciens mintája lett pozitív, a többi negatív eredményt adott.

A 465, sentinel orvostól származó minta mindegyike negatívnak bizonyult. Az 551, nem SARS-Cov-2-vizsgálatra érkező, fekvőbeteg-ellátó gyógyintézetből származó minta közül 550 negatív eredményt adott, 1 pedig pozitívnak bizonyult. Ez az egyetlen SARS-Cov-2-pozitív minta egy tracheaváladék volt, amely március 12-én, tehát az első esetek felderítése után érkezett a Laboratóriumba. A vizsgálatkérő lapon csak az influenza A, B, RSV és adenovírus irányában történő vizsgálatokat kérték. A kért vírusokra történő vizsgálat negatív eredményt adott, ezért a tünetek alapján a kezelőorvossal egyeztetve beállítottuk a SARS-CoV-2-PCR-vizsgálatot is. Így a beteg pozitivitása időben kiderült.

\section{Megbeszélés}

2019. december 31-én a kínai hatóságok tájékoztatták a WHO-t, hogy ismeretlen eredetû súlyos tüdőgyulladás okoz megbetegedéseket Vuhanban (Hupej tartomány). 2020. január 9-én jelentették be a kínai hatóságok, hogy azonosítottak egy új koronavírust, és január 12-én már a genetikai állományának pontos szekvenciáját is közzé tették. Az eredetileg Vuhan Coronavirusnak nevezett SARS-CoV-2 először csak Kínában terjedt, január közepén azonban kimutatták Japánban, Dél-Koreában és Thaiföldön, majd a régió több országában is. Január 23án jelentették az Egyesült Államokban a vírus megjelenését. Európában először 2020. január 25-én regisztráltak 3 esetet Franciaországban, majd azt követően Németországban is kimutatták a vírust [7].

Január végére a vírus kimutatható volt Olaszországban és Finnországban is. Ezt követően ugrásszerúen megnövekedett az európai esetek száma is [8]. Magyarországon a járvány kezdeti szakaszában az NNK Légúti Vírusok Nemzeti Referencia Laboratóriuma végezte egyedüliként a SARS-CoV-2-PCR-vizsgálatokat. A Laboratórium a nemzetközi protokollok alapján állította be a vizsgálatokat. Az első, kimutatásra alkalmas rendszerek már január végén rendelkezésre álltak, 2020. január 28-án történt meg az első SARS-CoV-2-PCR-vizsgálat.

Hazánkban először két iráni beteg mintájából, 2020. március 4-én sikerült kimutatni a vírust a Nemzeti Népegészségügyi Központban, majd Magyarországon is egyre több pozitív esetet diagnosztizáltak. 2020. július 31én 4505 fertőzöttről és 596 halálesetről tudunk [9].

Kínai kutatók retrospektív vizsgálatokat végeztek 2018. december 1. és 2020. március 31. közötti orr/ garat minták PCR-vizsgálatával, valamint vérminták 
IgG- és IgM-vizsgálatával [10]. A retrospektív vizsgálatok során nem találtak bizonyítékot arra, hogy korábban fertőződött volna valaki SARS-CoV-2-vel.

Franciaországi kutatók retrospektív vizsgálat alapján bizonyították, hogy a SARS-CoV-2 már egy hónappal az első, hivatalosan bejelentett eset előtt, 2019 decemberében jelen volt az országban [11]. Egy algériai illetőségú betegben mutatták ki, aki azonban nem hagyta el Franciaországot 2019 augusztusa óta.

Ezért különösen fontos volt megállapítani, hogy Magyarországon vajon jelen lehetett-e a vírus korábban, mint az első diagnosztizált eset. Természetesen biztosat még az összes tünetes beteg vizsgálata alapján sem lehetne állítani, hiszen lehetnek tünetmentesek a fertőzöttek. A WHO azonban az influenza megjelenésekor az influenzafigyelő szolgálat jelzőrendszerét tartja optimálisnak, ezért alkalmaztuk ugyanezt a rendszert a SARS-Cov-2-re is.

Az NNK Légúti vírusok Referencia Laboratóriumába 2020. január l. óta az ország teljes területéről beérkezett légúti minták vizsgálata alapján megállapítható, hogy a SARS-CoV-2 nagy valószínúséggel nem okozott súlyos, tünetes megbetegedéssel járó fertőzést Magyarországon 2020 márciusa előtt. Az először azonosított SARS-CoV2-pozitív minták importált esetekból származtak, később pedig az olasz, angol és osztrák pihenésról, összejövetelekről hazaérkezett magyar állampolgárok hurcolták be a vírust az országba.

A virológia és a járványügy tudománya kihívásokkal teli terület, és egy új kórokozó megjelenése kapcsán különösen sok kérdés merül fel a diagnosztikát, a népegészségügyi és gazdasági aspektusokat, terápiát és prevenciót illetően. Az NNK munkatársai számos tapasztalt szakemberrel együttmúködve, a járvány lecsengését követően is azon munkálkodnak, hogy ezekre a kérdésekre választ találjanak, és biztosítsák hazánk járványügyi stabilitását, kedvező helyzetét.

Anyagi támogatás: A közlemény megírása anyagi támogatásban nem részesült. Az etikai engedély száma: IV/5895-2/2020/EKU.

Szerzôi munkamegosztás: Sz. B., M. N.: A vizsgálatok megtervezése és a SARS-CoV-2-vizsgálatok végzése. D. D.: A SARS-CoV-2-vizsgálatok végzése. H. É.: A preanalitika szervezése. R. M.: A légúti mikrobiológiai surveillance koordinálása. M. Zs.: Az influenza surveillance múködtetése és felügyelete. K. D.: Influenzavizsgálatok végzése. K. Z., Sz. K., B. E.: Vizsgálatok megtervezése és értékelése, a kézirat belső véleményezése. T. M.: A vizsgálatok értékelése, a kézirat megírása. A cikk végleges változatát valamennyi szerző elolvasta és jóváhagyta.

Érdekeltségek: A szerzóknek nincsenek érdekeltségeik.

\section{Köszönetnyilvánítás:}

A magyarországi influenza surveillance múködése a részt vevő sentinel orvosok, a megyei influenzakoordinátorok, a Nemzeti Népegészségügyi Központ (NNK) járványügyi és laboratóriumi szakembereinek együttmúködésével történik, ezért az influenza surveillance munkájában közremúködő valamennyi kollégának köszönetünket fejezzük ki. A szerzők köszönik továbbá az NNK minden munkatársának hozzájárulását, akik a vizsgálatok elvégzésének bármelyik fázisában részt vettek, a laboratórium folyamatos múködését lehetővé tették, vagy bármilyen módon elősegítették. Külön köszönet az NNK COVID-munkacsoportjának áldozatos, kitartó munkájáért, különösen Áy Éva, dr. Dencs Ágnes, Nagy Anna, dr. Nagy Orsolya és Pályi Bernadett segítségéért.

\section{Irodalom}

[1] Lu R, Zhao X, Li J, et al. Genomic characterisation and epidemiology of 2019 novel coronavirus: implications for virus origins and receptor binding. Lancet 2020; 395: 565-574.

[2] Huang C, Wang Y, Li X, et al. Clinical features of patients infected with 2019 novel coronavirus in Wuhan, China. Lancet 2020; 395: 497-506. [Correction: Lancet 2020 Jan 30]

[3] WHO Coronavirus Disease (COVID-19) Dashboard. Available from: https://covid19.who.int/ [accessed: July 30, 2020].

[4] Rózsa M, Bán E. Coronaviridae. In: Takács M. (ed.) Clinical and Public Health Virology. [Koronavírusok. In: Takács M. (szerk.) Klinikai és járványügyi virológia.] Vox Medica Kiadói Kft., Veszprém, 2010; pp. 239-247. [Hungarian]

[5] Rókusz L, Jankovics I, Jankovics M, et al. Importance of the case of coronavirus-associated severe acute respiratory syndrome detected in Hungary in 2005. [Miért aktuális 2013-ban a súlyos akut respirációs szindrómát okozó koronavírus-fertőzés 2005ben Magyarországon igazolt esete?] Orv Hetil. 2013; 154: 1877-1882. [Hungarian]

[6] National Public Health Center. Sampling guidelines. [Nemzeti Népegészségügyi Központ. Mintavételi irányelvek.] Available from: https://www.nnk.gov.hu/attachments/article/217/ Mintaveteli\%20Iranyelvek.pdf [accessed: July 30, 2020]. [Hungarian]

[7] World Health Organization. Coronavirus disease (COVID-19) Weekly Epidemiological Update and Weekly Operational Update. Available from: https://www.who. int/emergencies/ diseases/novel-coronavirus-2019/situation-reports [accessed: July 30, 2020].

[8] Spiteri G, Fielding J, Diercke M, et al. First cases of coronavirus disease 2019 (COVID-19) in the WHO European Region, 24 January to 21 February 2020. Euro Surveill. 2020; 25: 2000178.

[9] Government portal. Information about Coronavirus Disease. [Kormányzati portál. Tájékoztató oldal a koronavírusról.] Available from: https:// koronavirus.gov.hu/ [accessed: July 30, 2020]. [Hungarian]

[10] Yu X, Wei D, Chen Y, et al. Retrospective detection of SARSCoV-2 in hospitalized patients with influenza-like illness. Emerg Microbes Infect. 2020; 9: 1470-1473.

[11] Deslandes A, Berti V, Tandjaoui-Lambotte Y, et al. SARS-CoV-2 was already spreading in France in late December 2019. Int J Antimicrob Agents 2020; 55: 106006.

(Takács Mária dr., Budapest, Albert Flórián út 2-6., 1097 e-mail: takacs.maria@nnk.gov.hu)

A cikk a Creative Commons Attribution 4.0 International License (https://creativecommons.org/licenses/by/4.0/) feltételei szerint publikált Open Access közlemény, melynek szellemében a cikk bármilyen médiumban szabadon felhasználható, megosztható és újraközölhető, feltéve, hogy az eredeti szerző és a közlés helye, illetve a CC License linkje és az esetlegesen végrehajtott módosítások feltüntetésre kerülnek. (SID_1) 